\title{
The Modeling of Leachate Distribution Potential in Rasau Jaya Landfill
}

\author{
R.M. Rustamaji ${ }^{1}$, Fitriana Meilasari ${ }^{2, *}$, Hendri Sutrisno ${ }^{2}$ \\ ${ }^{1}$ Department of Civil Engineering, Universitas Tanjungpura, Pontianak 78124, Indonesia \\ ${ }^{2}$ Department of Mining Engineering, Universitas Tanjungpura, Pontianak 78124, Indonesia \\ *Corresponding Author: fitriana@untan.ac.id
}

\section{Article history}

Received: 27.01.2021

Revised: 28.03.2021

Accepted: 25.04 .2021

DOI: $10.31629 /$ jit.v2i1.3202

\begin{abstract}
Rasau Jaya landfill applies an open dumping system. That system results in leachate that potential to cause environmental pollution. One of the efforts that can anticipate this problem is modeling the leachate distribution patterns. This study aimed to model the potential of leachate distribution below the surface both vertically and horizontally. The method using in this study to model leachate distribution patterns is the Wenner configuration geoelectric method. Results showed that the indicated leachate spread $30 \mathrm{~m}$ to the northeast and $30-40 \mathrm{~m}$ to the southwest. The most in-depth indication of leachate distribution is up to a depth of $20.3 \mathrm{~m}$.
\end{abstract}

Keywords: leachate distribution, landfill, Wenner configuration

\section{Introduction}

Kubu Raya Regency has a total population in 2018 of about 750,914 people with a population density of 82 people $/ \mathrm{km}^{2}$ [1]. That population caused a waste generation increase. Waste generation increase demands better waste management. One of the components of waste management is the final waste disposal site $[2,3,4]$. The landfill limitation and the lack of supporting facilities for waste management in the landfill causes a decrease in human life quality and increased environmental pollution.

Rasau Jaya landfill Kubu Raya Regency has practiced an open dumping system in waste management. That system produces leachate that caused pollute the environment $[5,6]$. Contents of leachate pollutants are nitrate, nitrite, ammonia, BOD, COD, heavy metals, etc. Those pollutants spread landfill area, so it endangers people's health around the landfill. The potential health problems that the surrounding community will feel include methemoglobinemia and poisoning [7]. The magnitude of the negative impact felt by the surrounding community. Therefore, it is necessary to have an appropriate landfill management effort. One of the leachate management efforts is modeling the potential distribution of leachate below the soil surface using the geoelectric method. The modeling results are in the form of a 2-dimensional picture related to the distribution leachate potential used to determine the appropriate follow-up efforts if leachate seepage exceeds the radius selected based on [8]. The research objective was to model the potential distribution of leachate below the surface both vertically and horizontally. 


\section{Materials and Methods}

\subsection{Materials}

The equipment used in this study are as follows:

1. Resistivity Meter

2. Global Positioning System (GPS)

3. Geological Compass

4. The meter

5. Electrodes

6. Cables

7. Res2Dinv Software

\subsection{Method}

The method used in this study for modeling the potential of leachate distribution is the Wenner configuration geoelectric method. The Wenner configuration advantage is data obtained more delicate and more accurate than other configurations [9]. The geoelectric method is expected to provide an overview of rock layer structures and indicate the underground's pollution distribution [10].

This study's stage consisted of surveying the research location, field data acquisition, data processing, and data interpretation. Research survey aims to make easy field data acquisition. That survey is critical because it will determine several things during the field data acquisition stage, such as deciding the geoelectric method's location, designing the path's length, choosing the starting and ending points, and the desired target depth.

The geoelectric method field data acquisition consists of 3 passes (Figure 1). The length of lines used in this method is $102-105 \mathrm{~m}$, and the distance between the electrodes is $3 \mathrm{~m}$. Geoelectric data processing uses Res2Dinv software [11]. Res2Dinv is computer software used to process data and displayed in 2 dimensions [12]. Analysis and interpretation of data based on resistivity value, geological, hydrogeological, and topographic, as presented on Fig. 1.

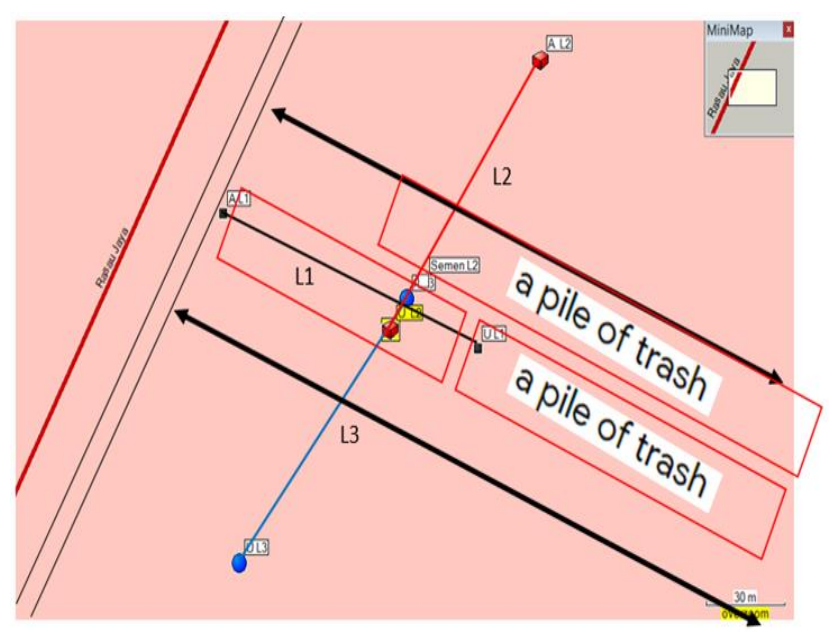

Figure 1. Geoelectric Data Retrieval Path

\section{Results and Discussion}

\subsection{The First Line}

Based on the results of the inverse modeling software Res2DInv that know the resistivity value in the first line is ranged $0.203-88.8$ ohm-meter and the RMS error of $10.6 \%$ (Figure 2). The resistivity value of $0.203-15.6$ ohm-meter interpreted leachate associated with peat soil (Zone A). The indication leachate value has a low resistivity value $(0.203$ ohm-meter $)$ because leachate is very conductive. The indication of leachate distribution tends evenly to be distributed from $0-72 \mathrm{~m}$. The prediction of the most in-depth distribution of leachate is $20.3 \mathrm{~m}$ (Figure 2).

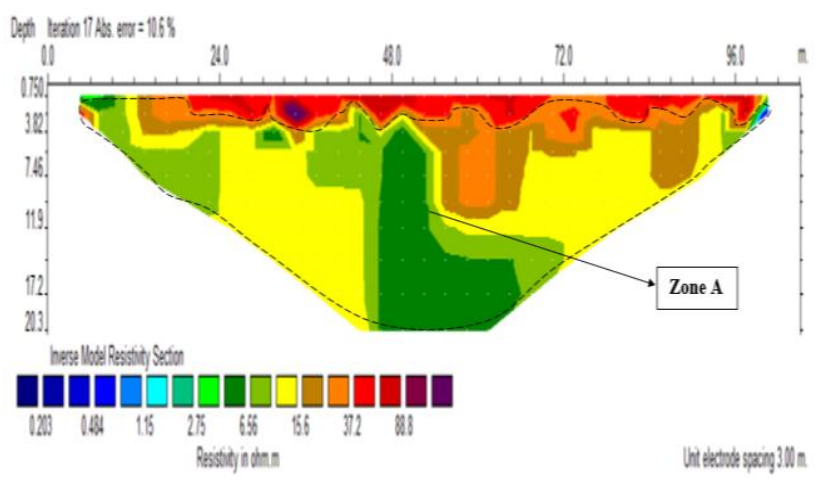

Figure 2. 2D cross-section for the first line 


\subsection{The Second Line}

The division of zone in field data acquisition on the second line is three zones: Zone A, Zone B, and Zone $\mathrm{C}$. The location of Zone A above the new garbage heap. At the same time, Zone B on old garbage piles. Zone $\mathrm{C}$ is located in an oil palm plantation near the Rasau Jaya landfill. Based on analysis and interpretation, the resistivity value of 2.41- 7.87 ohm-meter indicates peat soil contaminated by leachate. Guerin et al.'s research support this resistivity value (resistivity value of leachate was $<10$ ohm-meter) [13]. The indication of leachate distribution below the soil surface distributed from a stretch of $24-96 \mathrm{~m}$. The prediction of the most in-depth distribution of leachate is $20.3 \mathrm{~m}$.

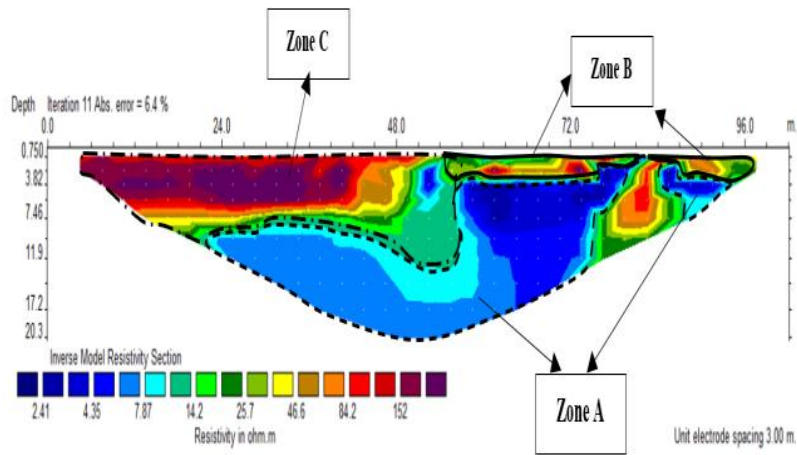

Figure 3. 2D cross-section for the second line

\subsection{The Third Line}

Potential of leachate distribution horizontally on the third line from a stretch of $6-78 \mathrm{~m}$. In contrast, the potential of leachate distribution is vertically distributed at a depth of $0.75-20.3 \mathrm{~m}$. The resistivity value indicated by leachate associated with peat soil is $3.89-11.2 \mathrm{ohm}$-meter with an error rate (error RMS) is $3.1 \%$ (Figure 4).

The study area's geological, hydrogeological, and topographic conditions influence underground leachate distribution potential. Based on the study area's geology, it is known Rasau Jaya landfill is mostly peat soil. Soil porosity and permeability influence the process of leachate infiltration into the ground. Soil porosity in the study area is mediumhigh, and soil permeability is low. Factors that influence soil porosity are the size and grain shape of the rock material, the grains' arrangement, the filling of the spaces between the grains by cement, and the difference in particle sizes. The study area's hydrogeological and topographic conditions also influence the leachate infiltration process into the soil. Rain intensity, slope steepness, soil surface material condition, vegetation, and infiltration capacity affect infiltration speed. The ground in the research area is sensitive to the compression force of rainfall to affect the value of soil permeability indirectly[14]. The research area is flat. This condition also affects the movement of leachate distribution below the surface both horizontally and vertically.

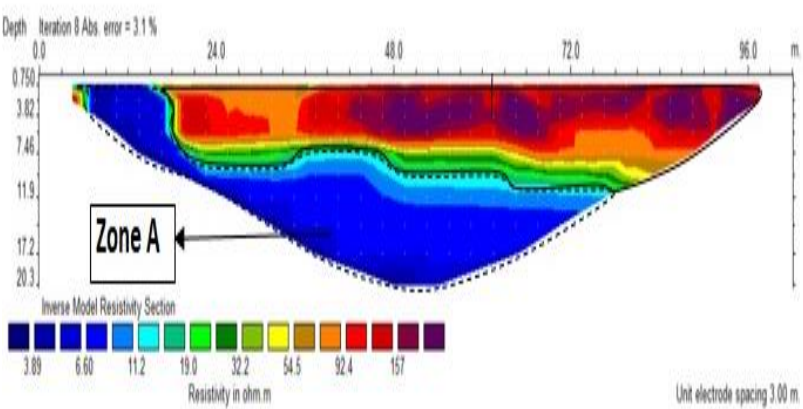

Figure 4. 2D cross-section for the third line

\section{Conclusion}

Resistivity value of $0.203-15.6$ ohm-meter is predicted leachate to be associated with peat soil. Indication potential of leachate distribution horizontally as far as $30 \mathrm{~m}$ to the northeast and 30$40 \mathrm{~m}$ to the southwest. The prediction of the most in-depth distribution of leachate vertically is at 20.3 meters.

\section{Acknowledgement}

The author would like to thank the Rector of Universitas Tanjungpura.

\section{References}

[1] Badan Pusat Statistik, 2019. Kabupaten Kuburaya Dalam Angka Tahun 2019. Kuburaya: Badan Pusat Statistik Kabupaten Kubu Raya.

[2] Sormunen K. Ettala M and Rintala, J. (2008, Des). Internal Leachate Quality in A Municipal Solid Waste Landfill: Vertical, Horizontal and Temporal Variation and Impacts of Leachate Recirculation. Journal of Hazardous Materials. 160 (2-3), PP. 601-607. Available : https://doi.org/10.1016/j.jhazmat.2008.03.081

[3] Bella DG. Trapani D D. Mannina, G and Viviani G. (2012, Marc). Modeling Of Perched Leachate Zone Formation in Municipal Solid Waste 
Landfills. Journal Waste Management. 32 (3), PP. 456-462. Available https://doi.org/10.1016/j.wasman.2011.10.025

[4] Kim JH. Endo D. Sato M. Matsuo T and Matsuto T. (2009, August), Estimation of Water Movement in A Closed Landfill Based on Tracer Tests in Gas Vents and Changes in Leachate Quality. Waste Management. 29 (8), PP. 23082315. Available https://doi.org/10.1016/j.wasman.2009.03.011.

[5] Hao Y-J. Wu W-Xi. Wu S-W. Sun H. and Chen Y-X. (2008, january). Municipal Solid Waste Decomposition Under Oversaturated Condition in Comparison with Leachate Recirculation. Process Biochemistry. 43 (1), PP. 108-112. Available: https://doi.org/10.1016/j.procbio.2007.10.004.

[6] Hardyanti, N and Huboyo, S.H. (2009, Marc). Evaluasi Instalasi Pengolahan Lindi Tempat Pembuangan Akhir Putri Cempo Kota Surakarta. Jurnal Presipitasi. 6 (1), PP. 52-56. Available: https://doi.org/10.14710/presipitasi.v6i1.52-56.

[7] Manampiring, A. E. "Studi Kandungan Nitrat $\left(\mathrm{NO}^{3}\right)$ pada Sumber air Minum masyarakat Kelurahan Rurukan Kecamatan Tomohon Timur Kota Tomohon." Universitas Sam Ratulangi, Laporan Penelitian. Oktober. 2009.

[8] Tata Cara Pemilihan Lokasi TPA, SNI No. 033241-1997, 1997.

[9] Khoiriyah Fitri, "Pemanfaatan Metode Geofisika Resistivitas Konfigurasi Wenner untuk menggambarkan Distribusi Resistivitas di Lahan Perkebunan Tebu Lahan Kering," Skirpsi. Fakultas Matematika dan Ilmu Pengetahuan Alam. Universitas Jember, Jember, 2017.
[10] Wijaya L," Identifikasi Pencemaran Airtanah Dengan Metode Geolistrik Di Wilayah Ngringo Jaten Karanganyar," Skripsi. Fakultas Matematika dan Ilmu Pengetahuan Alam. Universitas Sebelas Maret, Surakarta 2017.

[11] Herlin HS and Budiman A. (2015, October). Penentuan Bidang Gelincir Gerakan Tanah Dengan Aplikasi Geolistrik Metode Tahanan Jenis Dua Dimensi Konfigurasi WennerSchlumberger (Studi Kasus di Sekitar Gedung Fakultas Kedokteran Universitas Andalas Limau Manis, Padang). Jurnal Fisika Unpad. 1 (1), PP. 19-24. Available: https://doi.org/10.25077/jfu.1.1.\%25p.2012.

[12] Nugroho C. Darsono and Ramelan AH. (2018, January). Aplikasi Geolistrik Resistivitas Konfigurasi Wenner-Schlumberger untuk Pemetaan Sebaran Leachate di Sekitar TPA Putri Cempo Surakarta. Jurnal Fisika dan Aplikasinya. 14 (1), PP. 1-4. Available: http://dx.doi.org/10.12962/j24604682.v14i1.2864.

[13] Guerin, R., Munoz, L.M., Aran, C., Laperrelle, C., Hidra, M., Drouart, E., dan Grellier, S. (2004). Leachate recirculation: moisture content assessment by means of a geophysical technique. Journal Waste Management. 24 (8), PP. 785-794. Available : https://doi.org/10.1016/j.wasman.2004.03.010.

[14] Wibowo, H. ( 2010, January). Laju Infiltrasi pada Lahan Gambut yang Dipengaruhi Air Tanah (Study Kasus Sei Raya Dalam Kecamatan Sei Raya Kabupaten Kubu Raya). Jurnal Belian. 9 (1), Hal. 90 - 103. Available : http://repository.polnep.ac.id/xmlui/handle/123 $456789 / 146$. 